\title{
The Analysis of Junior High School Students' Mathematical Connection on The Ratio and Proportion Concepts
}

\author{
Ismiyanti Suci Pratiwi ${ }^{1, a)}$, Eyus Sudihartinih ${ }^{1}$ \\ ${ }^{1}$ Universitas Pendidikan Indonesia \\ Jalan Dr. Setiabudhi No. 229, Bandung 40154, Indonesia.
}

a) ismiyantisucip@upi.edu

\begin{abstract}
The purpose of this study was to obtain an overview of the mathematical connections of junior high school students on the concepts of ratio and proportion. This research uses a descriptive qualitative method with data triangulation. The research participants were four junior high school students in Sukabumi. The instrument used in this study consisted of a description test of three questions that had been consulted with experts and based on considerations regarding indicators of mathematical connection ability. Based on the results of the study, it is known that the ability of students to recognize and use connections between mathematical ideas is $50 \%$, the ability of students to connect and apply mathematical concepts with other disciplines is $50 \%$, and the ability of students to connect and apply mathematical concepts to problems in everyday life with a percentage of $50 \%$. The results showed that the mathematical connection ability of some junior high school students in Sukabumi on the concept of comparison was included in the poor category.
\end{abstract}

Keywords: Junior High School; Mathematical Connection; Qualitative Research; Ratio and Proportion

\begin{abstract}
Abstrak. Tujuan penelitian ini adalah untuk memperleh gambaran koneksi matematis siswa sekolah menengah pertama pada konsep rasio dan proporsi. Penelitian ini menggunakan metode kualitatif deskriptif dengan triangulasi data. Partisipan penelitian adalah empat orang siswa sekolah menengah pertama di Sukabumi. Instrumen yang digunakan dalam penelitian ini terdiri dari tes uraian sebanyak tiga soal yang telah dikonsultasikan dengan ahli dan berdasarkan pertimbangan mengenai indikator kemampuan koneksi matematis. Berdasarkan hasil penelitian diketahui bahwa kemampuan peserta didik dalam mengenali dan menggunakan koneksi antar ide-ide matematika dengan persentase sebesar 50\%, kemampuan peserta didik dalam mengkoneksikan dan menerapkan konsep matematika dengan disiplin ilmu lain dengan persentase sebesar 50\%, serta kemampuan peserta didik dalam mengkoneksikan dan menerapkan konsep matematika dengan permasalahan pada kehidupan sehari-hari dengan persentase sebesar 50\%. Hasil penelitian menunjukkan bahwa kemampuan koneksi matematis beberapa peserta didik sekolah menengah pertama di Sukabumi pada konsep perbandingan termasuk pada kategori kurang.
\end{abstract}

Kata kunci: Koneksi Matematika; Penelitian Kualitatif; Rasio dan Proporsi; Sekolah Menengah Pertama 


\section{INTRODUCTION}

The mathematical connection is an essential ability because with this ability students can connect various mathematical concepts to solve mathematical problems encountered. Students could also understand the usefulness and apply the relevance of mathematics to other disciplines as well as in everyday life. Without connections, students must learn and remember many separate concepts and skills (NCTM, 2000). Through mathematical connections, students can master the competence to explain the relationship between concepts and use concepts and algorithms, flexibly, accurately, efficiently, and precisely in solving problems. The ability to connect between mathematical concepts is called mathematical connection (Peraturan Menteri Pendidikan dan Kebudayaan Nomor 58 Tahun 2014). Furthermore, in the regulation it is written, the characteristics of mathematics in the learning process are connectedness between one subject and other subjects and can be applied to other disciplines. This means that students must master the previously studied subject matter to study the next subject matter and apply it to other disciplines.

The mathematical connection is the ability to connect conceptual and procedural knowledge, use mathematics on other topics, use mathematics in life activities, and use connections between topics in mathematics (Coxford in Siagian, 2016). Connecting various information obtained will help students understand the concept (Mulyani, 2018). With mathematical connections, students could build new understandings based on prior knowledge (Karim, 2014). Mathematical connections can remove barriers that separate mathematics learned in school from mathematics learned elsewhere. Thus the mathematical connection helps students see mathematics as a unit of knowledge, not as a complex and separate thing between concepts, procedures, and processes (NCTM, 2000). With this knowledge, students could understand mathematics more thoroughly and more deeply (Warih et al., 2016).

In fact that the mathematical connection of some students is relatively low. As a research report on $9^{\text {th }}$-grade of 22 Muhammadiyah Kisaran Junior High School, the percentage of the first indicator that is the relationship between mathematics and daily life is $51.11 \%$ so it belongs to the category of "not enough", and the percentage of the second indicator is the relationship between objects and concepts mathematics is $17.78 \%$ so it belongs to the category of "very less" (Siregar \& Surya, 2017). Besides, research reports conducted on $8^{\text {th }}$-grade of 7 Cimahi Public Middle School also known that the percentage of the first indicator that is the ability of students to recognize the relationship of different subjects in mathematics is $68.27 \%$, the percentage of the second indicator that uses mathematics in other discipline is $30.13 \%$, and the percentage of the third indicator that is using mathematics in daily life is $66.11 \%$ (Nurainah et al., 2018). According to other research reports conducted on $8^{\text {th }}$-grade of Darul Falah Bendiljati Madrasah Tsanawiyah, the average score on the first indicator that is the connection between topics in mathematics that links between the 
subject in a particular topic with the subject in other topics is 51.8 so that it belongs to the category of "less", the average score on the second indicator that is the connection between mathematics subject with other fields of science other than mathematics is 40.83 so that it belongs to the category of "very less", as well as the average score on the third indicator that is the connection between mathematics with daily life is 66.3 so it belongs to the "enough" category (Laili \& Puspasari, 2018). Other research reports in $8^{\text {th }}$-grade of 2 Tiworo Selatan Public Middle School known the percentage of the first indicator that is connecting between objects and mathematics is $46 \%$, the percentage of the second indicator that connects mathematics and daily life is $30 \%$, and the percentage of the third indicator that connecting mathematics with other sciences is $32 \%$. This shows that the students' mathematical connection is still low (Sudirman, 2017).

Some concepts that require the mathematical connection are the ratio and proportion because this concept is a substantial basic concept for understanding other mathematical concepts (Wahyuningrum et al., 2019). Also, the concept of the ratio and proportion often students meet in everyday life (Andini \& Jupri, 2016). The concept is studied at the junior high school level. Based on this description, it is known the importance of mathematical connection skills in the concept of ratio and proportion but there is no research report yet. Therefore, the purpose of this study was to obtain an overview of the mathematical connections of junior high school students on the concepts of ratio and proportion.

\section{METHOD}

The design of this research was descriptive qualitative following Sudihartinih's research (Sudihartinih, 2018). The design of this study can describe the students' mathematical connections by using the triangulation of data sources (interviews, documentation, and theory). The participants of this research were four students in $8^{\text {th }}$-grade at one of the junior high schools in Sukabumi, West Java.

This research instrument is the description test consisting of three questions that refer to mathematical connection indicators in NCTM (2000). The research instrument has been consulted with experts so the indicators used in this research are as follows: (1) Recognize and use connections between mathematical ideas. (2) Connect and apply mathematical concepts to other disciplines. (3) Connect and apply mathematical concepts with problems in everyday life.

These indicators can be measured and used sequentially in the following question of description test:

1. The ratio of the length and width of the rectangle is $7: 4$. The area of the rectangle is $252 \mathrm{~cm}^{2}$. What is the circumference of the rectangle? 
2. The temperature ratio shown by the Celsius thermometer $\left(t_{C}\right)$, Fahrenheit thermometer $\left(t_{F}\right)$, and the Reaumur thermometer $\left(t_{R}\right)$ are respectively as follows:

$\mathrm{t}_{\mathrm{C}}:\left(\mathrm{t}_{\mathrm{F}}-32\right): \mathrm{t}_{\mathrm{R}}=5: 9: 4$

If the liquid is measured using a Reaumur thermometer, the temperature is $38^{\circ}$ Reaumur. What is the temperature of the liquid if that measured using a Fahrenheit thermometer?

3. A room construction project undertaken by 11 people is expected to be completed within 23 days. So that the room construction project could be completed within 11 days, what is the additional amount of labor needed?

Data collection is done by asking participants to answer the description test about the concept of the ratio and proportion and proceed with interviews. The time provided for taking the test is 45 minutes. The test is done individually and the test is given after students learn the concept of the ratio and proportion. Then the interview is conducted after the students answer the test given. Interviews were changed to transcripts form for analysis. Furthermore, participants' answers could be measured using the assessment rubric as follows (Wardina \& Sudihartinih, 2019):

Table 1. Assessment Rubric

\begin{tabular}{|c|c|c|}
\hline Indicator & Students' Responses to Questions & Score \\
\hline \multirow{5}{*}{$\begin{array}{l}\text { Students can recognize and use } \\
\text { connections between mathematical ideas. }\end{array}$} & No answer. & 0 \\
\hline & The answers do not match the questions. & 1 \\
\hline & Able to answer questions but not yet able to connect. & 2 \\
\hline & $\begin{array}{l}\text { Able to answer questions, able to connect, but the final } \\
\text { results obtained are wrong. }\end{array}$ & 3 \\
\hline & $\begin{array}{l}\text { Able to answer questions, able to connect, and the final } \\
\text { results obtained are correct. }\end{array}$ & 4 \\
\hline \multirow{5}{*}{$\begin{array}{l}\text { Students can connect and apply } \\
\text { mathematical concepts to other } \\
\text { disciplines. }\end{array}$} & No answer. & 0 \\
\hline & The answers do not match the questions. & 1 \\
\hline & Able to answer questions but not yet able to connect. & 2 \\
\hline & $\begin{array}{l}\text { Able to answer questions, able to connect, but the final } \\
\text { results obtained are wrong. }\end{array}$ & 3 \\
\hline & $\begin{array}{l}\text { Able to answer questions, able to connect, and the final } \\
\text { results obtained are correct. }\end{array}$ & 4 \\
\hline \multirow{5}{*}{$\begin{array}{l}\text { Students can connect and apply } \\
\text { mathematical concepts with problems in } \\
\text { everyday life. }\end{array}$} & No answer. & 0 \\
\hline & The answers do not match the questions. & 1 \\
\hline & Able to answer questions but not yet able to connect. & 2 \\
\hline & $\begin{array}{l}\text { Able to answer questions, able to connect, but the final } \\
\text { results obtained are wrong. }\end{array}$ & 3 \\
\hline & $\begin{array}{l}\text { Able to answer questions, able to connect, and the final } \\
\text { results obtained are correct. }\end{array}$ & 4 \\
\hline
\end{tabular}

To calculate the percentage of total scores from each mathematical connection indicator $(\mathrm{Pk})$, the following calculations can be used: 


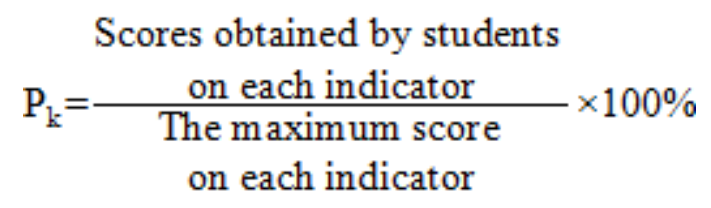

The mathematical connection of students on each indicator can be classified as follows:

Table 2. Classification of Mathematical Connections in Each Indicator

\begin{tabular}{cc}
\hline Percentage & Classification \\
\hline $85 \leq \mathrm{Pk} \leq 100$ & Very good \\
$70 \leq \mathrm{Pk} \leq 84,99$ & Good \\
\hline $55 \leq \mathrm{Pk} \leq 69,99$ & Enough \\
\hline $40 \leq \mathrm{Pk} \leq 54,99$ & Less \\
\hline $0 \leq \mathrm{Pk} \leq 39,99$ & Very less \\
\hline
\end{tabular}

\section{RESULTS AND DISCUSSION}

Based on the research that has been carried out, here are the results.

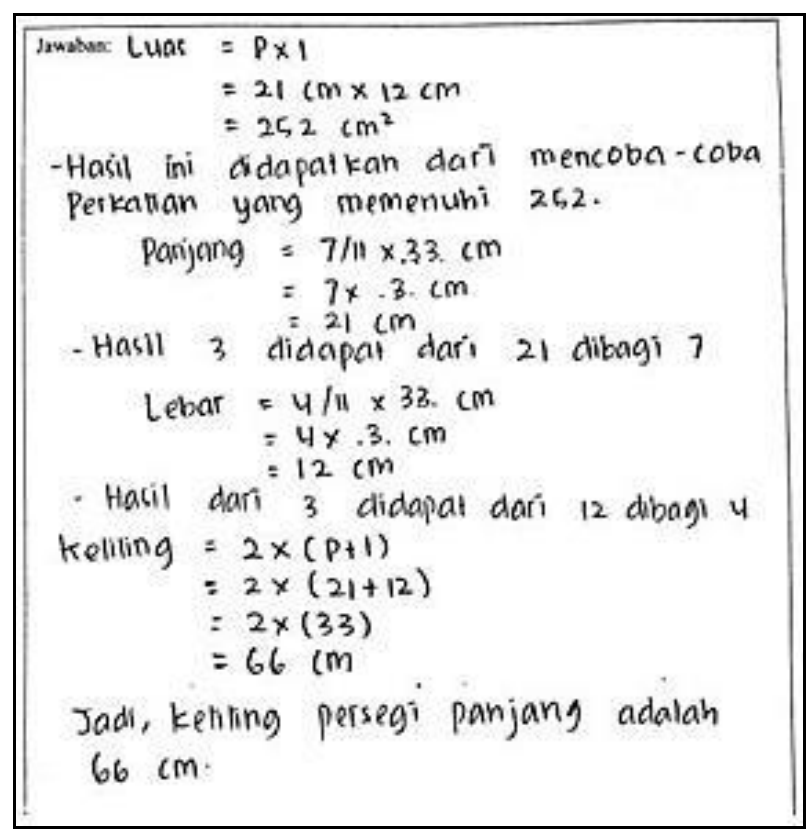

Figure 1. The Answer to Question Number 1 from Participant 1

Based on Figure 1, participant 1 answers question number 1 and the answer is correct. However, participant 1 did not connect the concept of the plane with the concept of the ratio and proportion to get the actual length and width values to determine the circumference of the rectangle. 


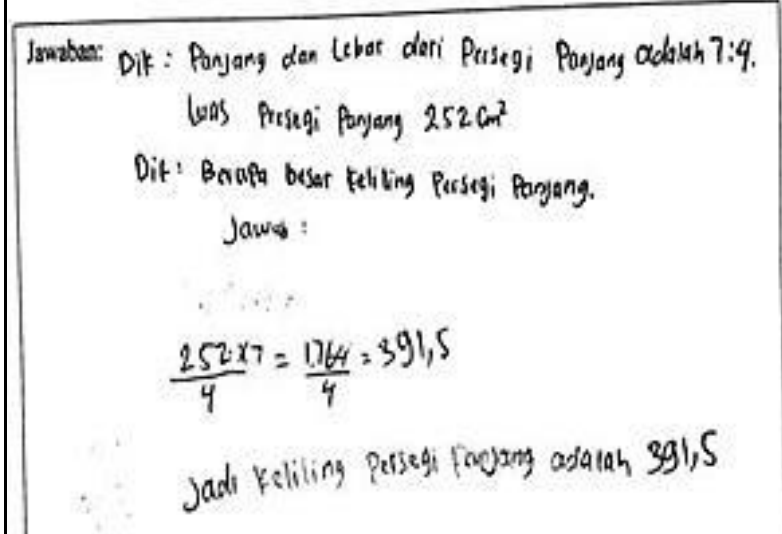

Figure 2. The Answer to Question Number 1 from Participant 2

Based on Figure 2, participant 2 answers question number 1 but the answer is still not quite right. Besides, participant 2 did not connect the concept of the plane with the concept of the ratio and proportion to get the actual length and width values to determine the circumference of the rectangle. The formula to determine the circumference of the rectangle is not quite right. In the calculation of algebraic operations, errors were still found.

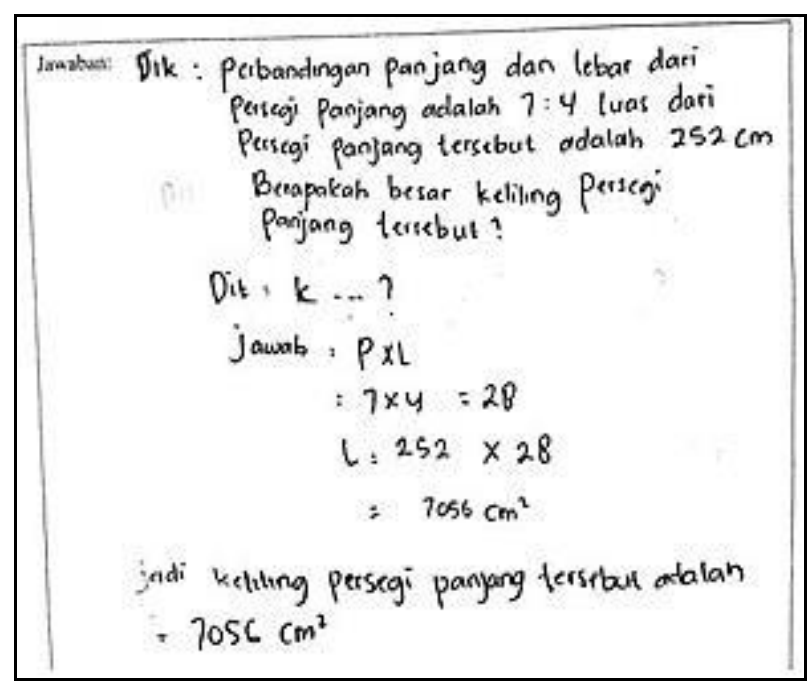

Figure 3. The Answer to Question Number 1 from Participant 3

Based on Figure 3, participant 3 answers question number 1 but the answer is still not quite right. Also, participant 3 did not connect the concept of the plane with the concept of the ratio and proportion to get the actual length and width values to determine the circumference of the rectangle. The formula to determine the circumference of a rectangle is still not quite right. 


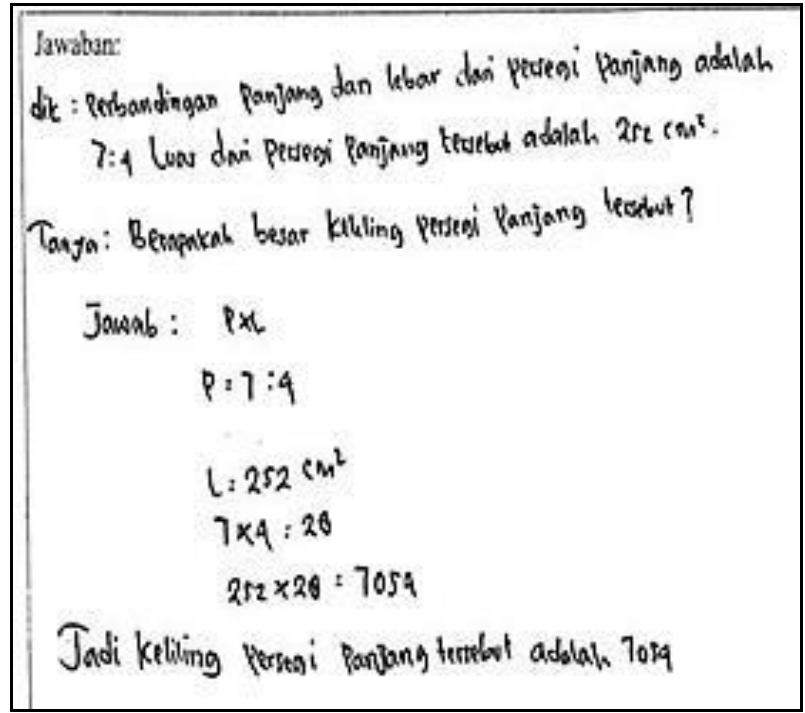

Figure 4. The Answer to Question Number 1 from Participant 4

Based on Figure 4, participant 4 answers question number 1 but the answer is still not quite right. Besides, participant 4 did not connect the concept of the plane with the concept of the ratio and proportion to get the actual length and width values to determine the circumference of the rectangle. The formula to determine the circumference of a rectangle is still not quite right.

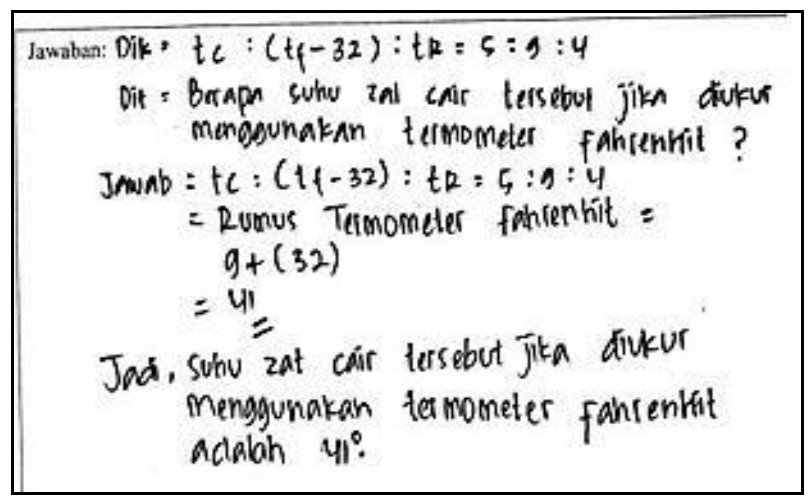

Figure 5. The Answer to Question Number 2 from Participant 1

In Figure 5, it can be seen that participant 1 answered question number 2 but the answer was still not quite right. Besides, participant 1 did not connect the concept of the temperature measurement with the concept of the ratio and proportion to get the temperature of a liquid if that measured using a Fahrenheit thermometer. 


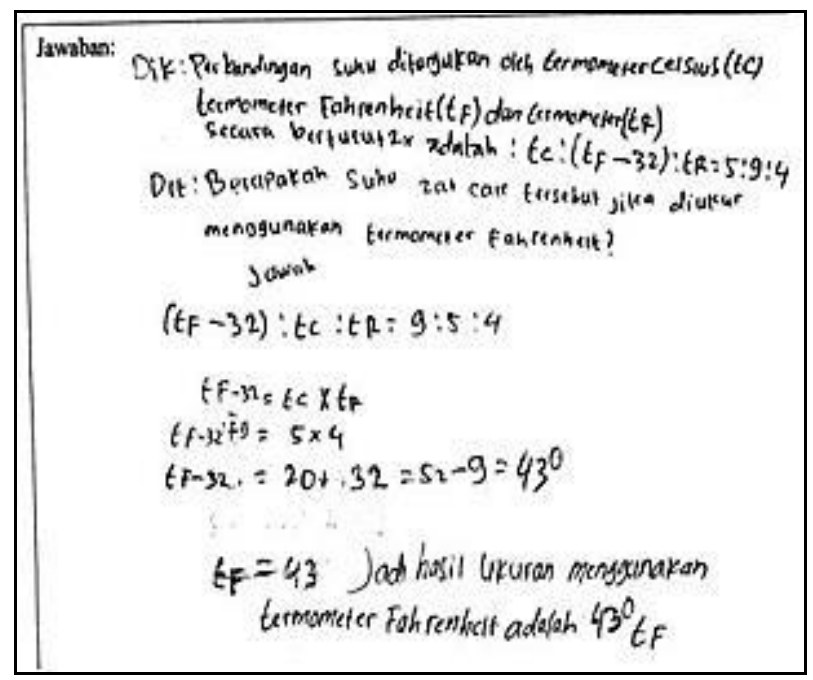

Figure 6. The Answer to Question Number 2 from Participant 2

In Figure 6, it can be seen that participant 2 answers question number 2 but the answer is still not quite right. Also, participant 2 did not connect the concept of temperature measurement with the concept of the ratio and proportion to get the temperature of a liquid if that measured using a Fahrenheit thermometer.

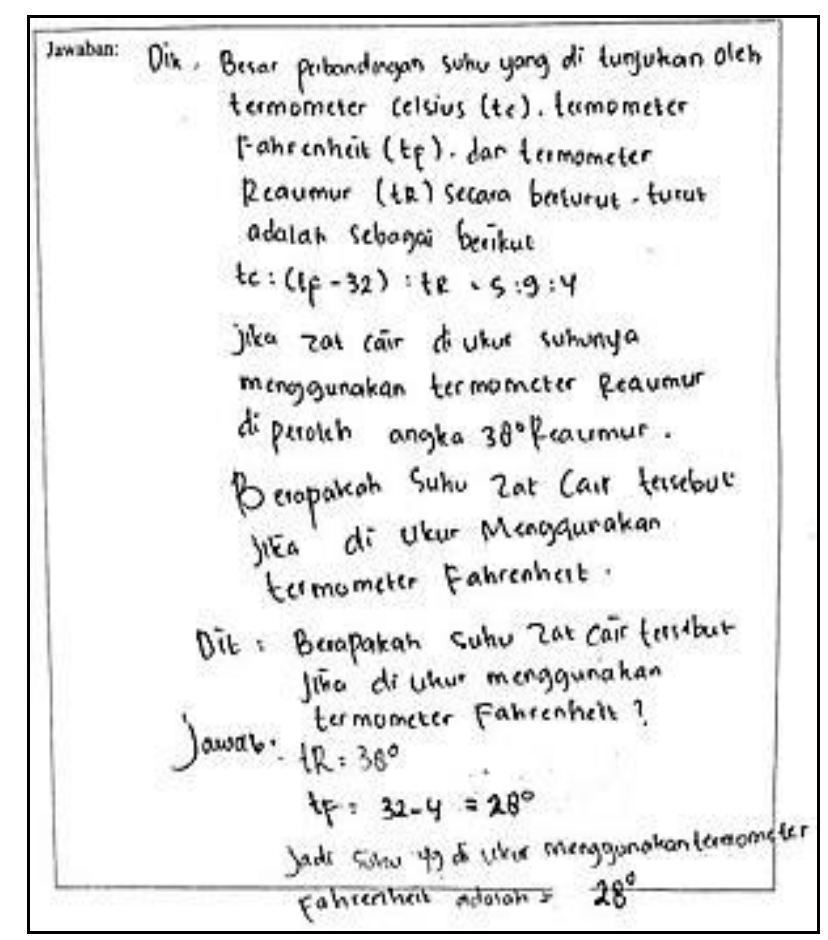

Figure 7. The Answer to Question Number 2 from Participant 3

In Figure 7, it can be seen that participant 3 answers question number 2 but the answer is still not quite right. Besides, participant 2 did not connect the concept of the temperature measurement with the concept of the ratio and proportion to get the temperature of a liquid if that measured using a Fahrenheit thermometer. 


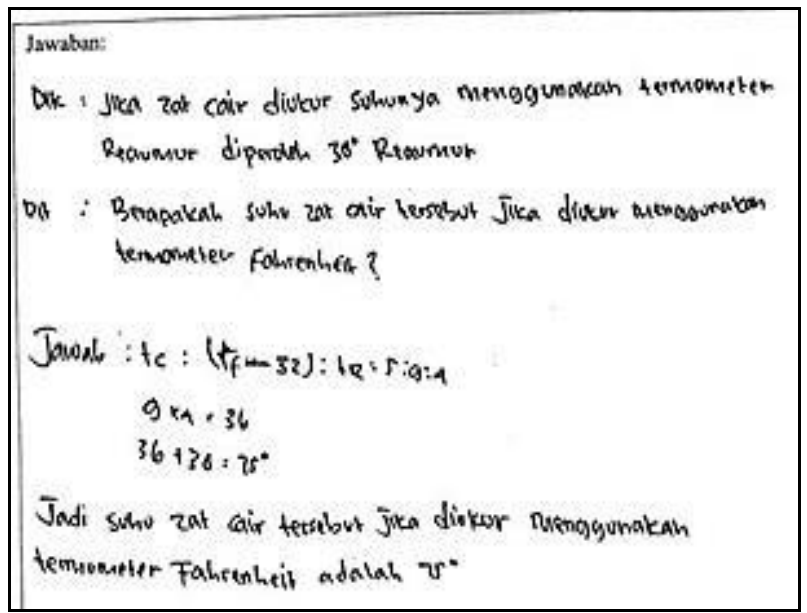

Figure 8. The Answer to Question Number 2 from Participant 4

In Figure 8, it can be seen that participant 4 answers question number 2 but the answer is still not quite right. Also, participant 4 did not connect the concept of the temperature measurement with the concept of the ratio and proportion to get the temperature of a liquid if that measured using a Fahrenheit thermometer.

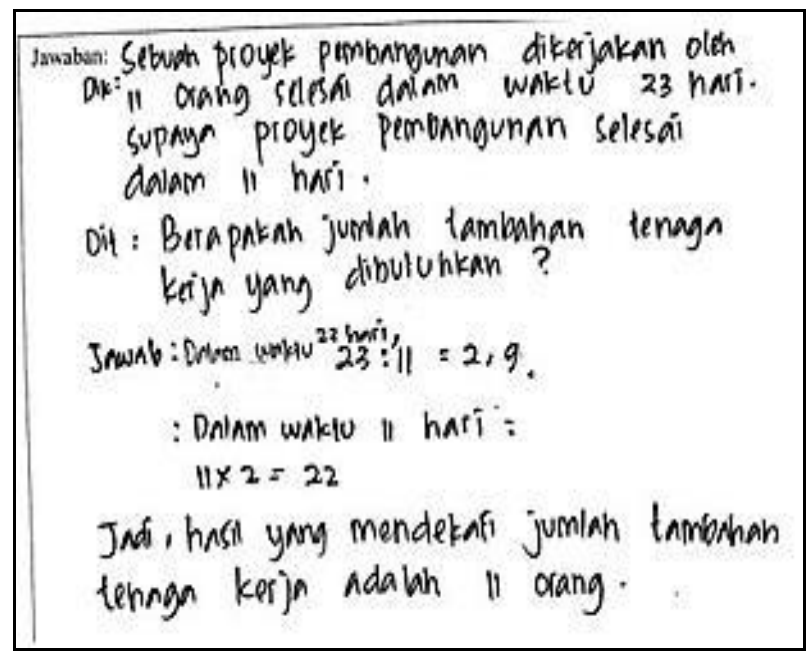

Figure 9. The Answer to Question Number 3 from Participant 1

According to the results in Figure 9, participant 1 answered question number 3 but the answer was still not quite right. Besides, participant 1 did not connect the existing problems in daily life with the concept of the ratio and proportion to get the value in question. 


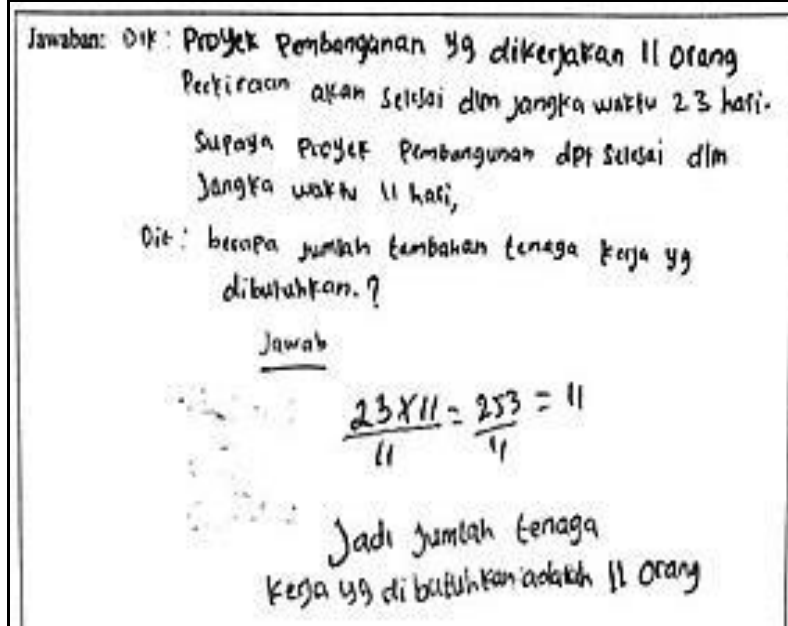

Figure 10. The Answer to Question Number 3 from Participant 2

According to the results in Figure 10, participant 2 answers question number 3 but the answer is still not quite right. Also, participant 1 did not connect the existing problems in daily life with the concept of the ratio and proportion to get the value in question.

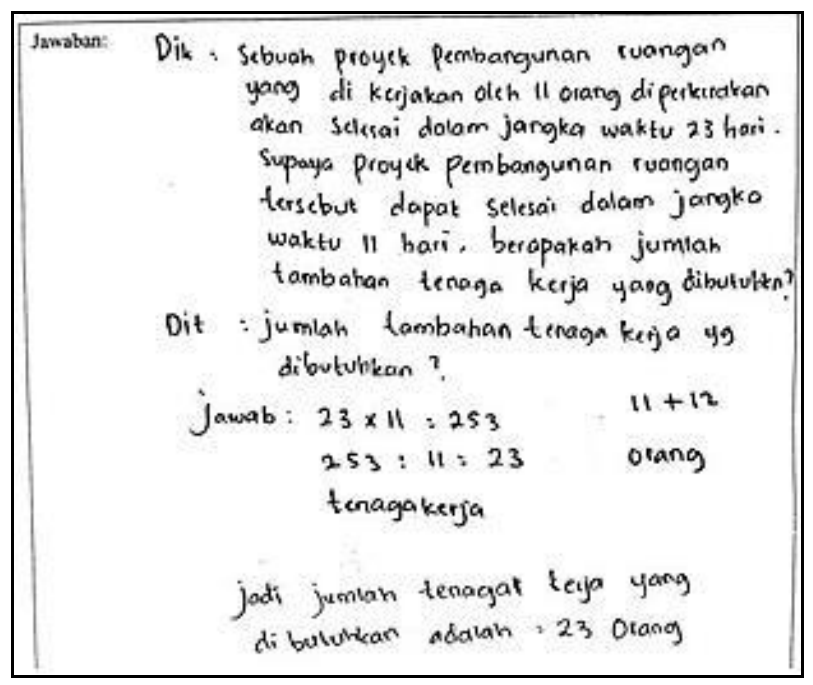

Figure 11. The Answer to Question Number 3 from Participant 3

According to the results in Figure 11, participant 2 answers question number 3 but the answer is still not quite right. Besides, participant 1 did not connect the existing problems in daily life with the concept of the ratio and proportion to get the value in question. 


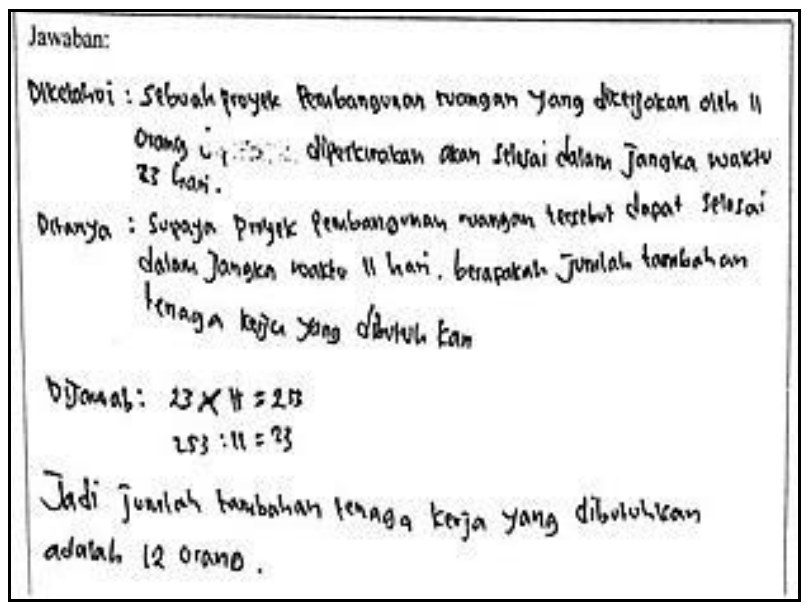

Figure 12. The Answer to Question Number 3 from Participant 4

According to the results in Figure 12, participant 4 answers question number 3 and the answer is correct. However, participant 4 did not connect the problems that exist in everyday life with the concept of the ratio and proportion to get the value in question.

The following are the results of interviews with participants in the transcripts form:

\section{Participant 1}

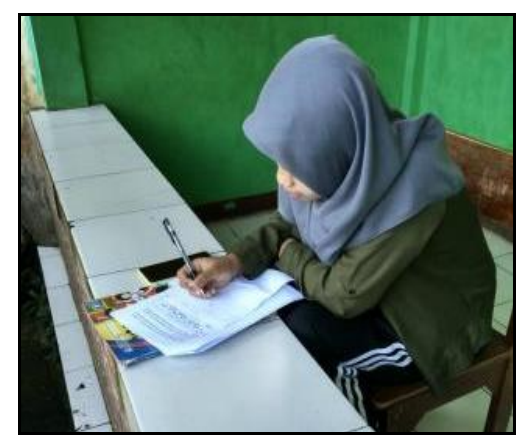

Figure 13. Participants 1 Doing the Test

Researcher : "Assalamu'alaikum, participant 1. How to solve problem number 1?"

Participant 1 : "Wa'alaikumussalam. So problem number 1 is known that the ratio of the length and width of the rectangle is $7: 4$. The area of the rectangle is $252 \mathrm{~cm}^{2}$, what is the circumference of the rectangle? The answer is an area equal to the length multiplied by the width equal to $21 \mathrm{~cm}$ multiplied by $12 \mathrm{~cm}$, equal to $252 \mathrm{~cm}^{2}$. This result was obtained from trial and error multiplication which fulfilled 252. The length $=\frac{T}{11} \times 33 \mathrm{~cm}=7 \times 3 \mathrm{~cm}=21 \mathrm{~cm}$, a result of 3 is obtained from 21 divided by 7. The width $=\frac{4}{11} \times 33 \mathrm{~cm}=4 \times 3 \mathrm{~cm}=12 \mathrm{~cm}$. Result of 3 is obtained from 12 divided by 4 .

The circumference $=2 \times($ length + width $)=$ 
$2 \times(21+12)=2 \times 33=66 \mathrm{~cm}$. So the circumference of the rectangle is $66 \mathrm{~cm}$."

Researcher : "Are you sure about that answer?"

Participant 1 : "I think that sure because it has been repeated and the results have not changed."

Researcher : "Then how do you solve problem number 2?"

Participant 1: "Number 2, the temperature ratio shown by the Celsius thermometer $\left(\mathrm{t}_{\mathrm{C}}\right)$, Fahrenheit thermometer $\left(t_{F}\right)$, and Reaumur thermometer $\left(t_{R}\right)$ respectively are as follows, $t_{C}:\left(t_{F}-32\right): t_{R}=5: 9: 4$. If the liquid is measured using a Reaumur thermometer, the temperature is $38^{\circ}$ Reaumur. What is the temperature of the liquid if that measured using a Fahrenheit thermometer? The answer is $t_{C}:\left(t_{F}-32\right)$ $: t_{R}=5: 9: 4$, The formula of Fahrenheit thermometer is plus 32, so 9 plus 32 is equal to $41^{\circ}$. I find it difficult to answer question number $2 . "$

Researcher : "Then how do you solve problem number 3?"

Participant 1 : "It is known that a room construction project undertaken by 11 people is expected to be completed within 23 days. So that the room construction project could be completed within 11 days, what is the additional amount of labor needed? The answer is in 23 days was done by 11 people, I divide 23 by 11, the result was 2,9 and in 11 days, I multiply 2 , so it is equal to 22 days. So the result that is close to the number of additional labor is 11 people."

Researcher : "In your opinion, what number is the most difficult question?"

Participant 1 : "In my opinion, the most difficult question is number 2."

Researcher : "Okay, thank you."

Participant 1 : "Yes, you are welcome."

\section{Participant 2}

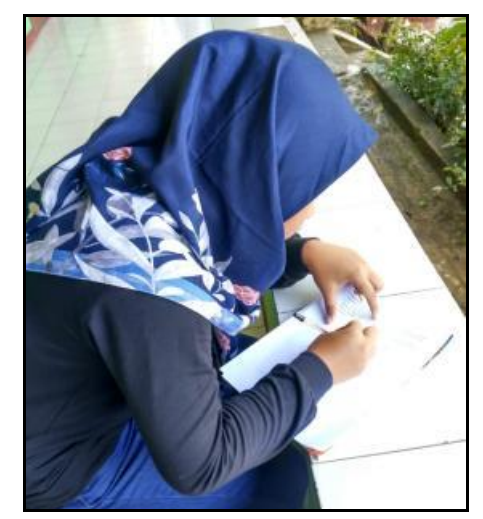

Figure 14. Participants 2 Doing the Test

Researcher : “Assalamu'alaikum, participant 2. How to solve problem number 1?" 
Participant 2: "Wa'alaikumussalam. Number 1 is known that the ratio of the length and width of the rectangle is $7: 4$. The area of the rectangle is $252 \mathrm{~cm}^{2}$, what is the circumference of the rectangle? The answer is 252 times 7 is 1.764 .1 .764 divided by 4 is 391.5 . So the circumference of the rectangle is $391.5 \mathrm{~cm}$."

Researcher : "Are you sure about that answer?"

Participant 2 : "I think I'm sure."

Researcher : "Then how do you solve problem number 2?"

Participant 2 : "The temperature ratio shown by the Celsius thermometer $\left(t_{C}\right)$, Fahrenheit thermometer $\left(t_{F}\right)$, and Reaumur thermometer $\left(t_{R}\right)$ respectively are as follows, $t_{C}:\left(t_{F}-32\right): t_{R}=5: 9: 4$. Asked what the temperature of the liquid if that measured using a Fahrenheit thermometer. The answer is $\left(t_{F}-32\right): t_{C}: t_{R}=9: 5: 4 . t_{F}$ minus 32 is equal to $t_{C}$ multiplied $t_{R}$. $t_{F}$ minus 32 plus 9 is equal to 5 multiplied $4 . t_{F}$ is equal to 20 plus 32 , the result is 52.52 minus 9 the result is $43^{\circ}$. So the measurement results using the Fahrenheit thermometer are $43^{\circ}$."

Researcher : "What do you think about question number 2?"

Participant 2 : "I find it difficult to answers questions number 2."

Researcher : "Then how do you solve problem number 3?"

Participant 2 : "It is known that a room construction project undertaken by 11 people is expected to be completed within 23 days. So that the room construction project could be completed within 11 days, what is the additional amount of labor needed? The answer is 23 times 11 the results are 253,253 divided by 11 the results are 11 . So the number of laborers needed is 11 people. "

Researcher : "From that question, what number is the most difficult question?"

Participant 2 : "Question number 2."

Researcher : "Okay, thank you."

Participant 2 : "Yes, you are welcome."

\section{Participant 3}

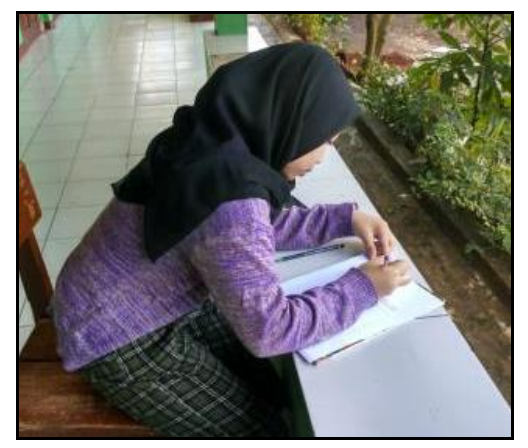

Figure 15. Participants 3 Doing the Test 
Researcher : "Assalamu'alaikum, participant 3. How to solve problem number 1?"

Participant 3 : "Wa'alaikumussalam. Question number 1 is known that the ratio of the length and width of the rectangle is $7: 4$. The area of the rectangle is $252 \mathrm{~cm}^{2}$, what is the circumference of the rectangle? The answer is length multiplied by width, so 7 multiplied by 4 is 28 . The area equals $252 \mathrm{~cm}^{2}$ multiplied 28 equal to $7.056 \mathrm{~cm}^{2}$."

Researcher : "Are you sure about that answer?"

Participant 3 : "Insya Allah, I'm sure with the answer."

Researcher : "Then, how do you solve problem number 2?"

Participants 3: "Known that the temperature ratio shown by the Celsius thermometer $\left(t_{C}\right)$, Fahrenheit thermometer $\left(t_{\mathrm{F}}\right)$, and the Reaumur thermometer $\left(\mathrm{t}_{\mathrm{R}}\right)$ are respectively as follows:

$t_{C}:\left(t_{F}-32\right): t_{R}=5: 9: 4$.

If the liquid is measured using a Reaumur thermometer, the temperature is $38^{\circ}$ Reaumur. What is the temperature of the liquid if that measured using a Fahrenheit thermometer? The answer is $t_{R}$ equal to $38, t_{F}$ equal to 32 minus 4 , equal to 28 . So, the temperature measured using a Fahrenheit thermometer is $28^{\circ} . "$

Researcher : "What do you think about question number 2?"

Participant 3 : "I think question number 2 is very difficult and I cannot understand it."

Researcher : "Then how do you solve problem number 3?"

Participant 3 : "Question number 3 is known that a room construction project undertaken by 11 people is expected to be completed within 23 days. So that the room construction project could be completed within 11 days, what is the additional amount of labor needed? What was asked was the additional labor needed. So the answer is 23 multiplied 11 is equal to $253 \mathrm{~cm}^{2}, 253 \mathrm{~cm}^{2}$ divided by 11 , the answer is 23 laborers (11 plus 12). "

Researcher : "In your opinion, what number is the most difficult question?"

Participant 3 : "In my opinion, the most difficult are number 2 and number 3 because the problem is very incomprehensible to me."

Researcher : "Okay, thank you."

Participant 3 : "Yes, you are welcome." 


\section{Participant 4}

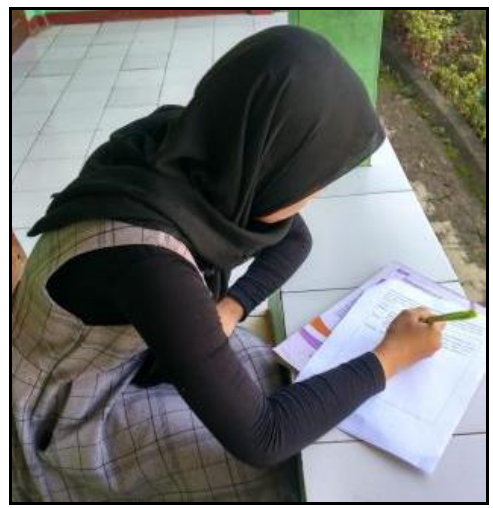

Figure 16. Participants 4 Doing the Test

Researcher : "Assalamu'alaikum, participant 4. How to solve problem number 1?"

Participant 4 : "Wa'alaikumussalam. In my opinion, it is known that the ratio of the length and width of the rectangle is $7: 4$. The area of the rectangle is $252 \mathrm{~cm}^{2}$. Asked what the circumference of the rectangle. The answer is length multiplied width, the length is $7: 4$, the width is $252 \mathrm{~cm}^{2} .7$ multiplied 4 is 28,252 multiplied 28 is 7.054 . So the circumference of the rectangle is $7.054 \mathrm{~cm} . "$

Researcher : "Are you sure about that answer?"

Participant 4: "Yes, I'm sure of the answer."

Researcher : "Then how do you solve problem number 2?"

Participant 4 : "In my opinion, it is known if the liquid was measured using a Reaumur thermometer, it was $38^{\circ}$ Reaumur. Asked how much the temperature of the liquid is that measured using a Fahrenheit thermometer $\left(t_{F}\right)$. The answer is $t_{C}:\left(t_{F}-32\right)$ : $t_{R}=5: 9: 4,9 \times 4=36.36^{\circ}+38^{\circ}=75^{\circ}$. So, the temperature of the liquid if that measured using a Fahrenheit thermometer is $75^{\circ} . "$

Researcher : "What do you think about question number 2?"

Participant 4 : "In my opinion, problem number 2 is very difficult."

Researcher : "Then how do you solve problem number 3?"

Participant 4 : "So in my opinion, it is known a room construction project undertaken by 11 people is expected to be completed within 23 days. So that the room construction project could be completed within 11 days, what is the additional amount of labor needed? The answer is 23 multiplied 11 is 253,253 divided by 11 is 23 . So the additional labor needed is 12 people."

Researcher : Where did the 12 as the results come from?

Participant 4 : "23 minus 11, so 12 people."

Researcher : "In your opinion, what number is the most difficult question?" 
Participant 4 : "In my opinion, the most difficult question is number 2."

Researcher : "Okay, thank you."

Participant 4 : "Yes, you are welcome."

The results showed that the mathematical connections of some $8^{\text {th }}$-grade students at one of the junior high schools in Sukabumi are in the "less" category. Students have not been able to recognize and use connections between mathematical ideas because in working on problems given students do not connect the concept of the plane with the concept of ratio and proportion to obtain answers. Students also have not been able to connect and apply mathematical concepts to other disciplines because in working on problems given students do not connect the concept of temperature measurement with the concept of the ratio and proportion to obtain answers. Besides, students have not been able to connect and apply mathematical concepts with problems in everyday life because in working on problems given students do not connect problems in everyday life with the concept of the ratio and proportion to obtain answers.

Based on the instruments that have been tested, each student's score is obtained on each indicator of mathematical connections following the number order of the description test. The scores and percentages obtained are as follows:

Table 3. Scores and Percentage of Mathematical Connections

\begin{tabular}{cccc}
\hline & Score on Each Indicator & \\
\cline { 2 - 4 } Participants & $\begin{array}{c}\text { Students can recognize } \\
\text { and use connections } \\
\text { between mathematical } \\
\text { ideas }\end{array}$ & $\begin{array}{c}\text { Students can connect } \\
\text { and apply mathematical } \\
\text { concepts to other } \\
\text { disciplines }\end{array}$ & $\begin{array}{c}\text { Students can connect and } \\
\text { apply mathematical concepts } \\
\text { with problems in everyday } \\
\text { life }\end{array}$ \\
\hline Participant 1 & 2 & 2 & 2 \\
\hline Participant 2 & 2 & 2 & 2 \\
\hline Participant 3 & 2 & 2 & 2 \\
\hline Participant 4 & 2 & 2 & 2 \\
\hline Total Score & 8 & 8 & 8 \\
\hline Total Maximum Score & 16 & 16 & 16 \\
\hline Percentage & $50 \%$ & $50 \%$ & $50 \%$ \\
\hline Category & Less & Less & Less \\
\hline
\end{tabular}

From these data, the total score obtained from indicator 1 is 8 of the total maximum score of indicator 1 which is 16 , the total score of indicator 2 is 8 of the total maximum score of indicator 2 which is 16 , and the total score of indicator 3 is 8 of the total maximum score of indicator 3 which is 16 .

The result from this research is also following previous research reports which show that students' mathematical connections are still lacking (Sugiman, 2008; Rawa et al., 2016; Nursaniah et al., 2018; Zuyyina et al., 2018; Jalaludin et al., 2018; Aspuri \& Pujiastuti, 2019; Nazaretha et al., 
2019). Based on the result of the research, here are some suggestions are given. (1) Teachers are encouraged to provide learning related to mathematical connections more depth and more varied in learning mathematics. Because with deeper and more varied learning, students are expected to be able to solve problems not only by memorizing formulas but by connecting their understandings. (2) There must be further research on the causes of the lack of mathematical connections of students as well as on ways to improve students' mathematical connections (Siregar \& Surya, 2017).

\section{CONCLUSION}

Based on the description and discussion from the results of research that has been done, it can be concluded that the percentage of mathematical connection of some students on the first indicator is $50 \%$, the second indicator is $50 \%$, and the third indicator is $50 \%$. Thus the mathematical connection of some $8^{\text {th }}$-grade students at one of the junior high schools in Sukabumi on the concept of the ratio and proportion is included in the "less" category.

\section{ACKNOWLEDGMENTS}

Researchers would like to thank all the participants who have contributed to this research until it can be completed.

\section{REFERENCES}

Andini, W., \& Jupri, A. (2016). International Conference on Recent Trends in Physics 2016 (ICRTP2016). Journal of Physics: Conference Series, 755(1), 011001.

Aspuri, \& Pujiastuti, H. (2019). Kemampuan Koneksi Matematis Siswa SMP dalam Menyelesaikan Soal Cerita: Studi Kasus di SMP Negeri 3 Cibadak. JIPM (Jurnal Ilmiah Pendidikan Matematika), 7(2), $124-131$.

Jalaludin, M., Rohaeti, E. E., \& Afrilianto, M. (2018). Analisis Kemampuan Koneksi Matematis Siswa MTs Kelas VII pada Materi Segitiga dan Segiempat. JPMI (Jurnal Pembelajaran Matematika Inovatif), $1(4), 695-702$.

Karim. (2014). Profil Berpikir Membuat Koneksi Matematis dalam Menyelesaikan Masalah Matematika Kontekstual (Suatu Tinjauan Teoritis). Prosiding Seminar Nasional Matematika Dan Pendidikan Matematika, 131-140.

Laili, F. J., \& Puspasari, R. (2018). Analisis Kesulitan Belajar Matematika Siswa Ditinjau dari Kemampuan Koneksi Matematika. Jurnal Pendidikan Dan Pembelajaran Matematika (JP2M), 4(2), 1-10.

Peraturan Menteri Pendidikan dan Kebudayaan Nomor 58 Tahun 2014 tentang Kurikulum 2013 Sekolah Menengah Pertama/Madrasah Tsanawiyah.

Mulyani. (2018). Pengaruh Model Pembelajaran Connection-Organizingreflecting-Extending (Core) terhadap Peningkatan Pemahaman Konsep dan Kemampuan Koneksi Matematis Siswa Kelas VIII SMP Negeri Se-Kota Padang. Residu Journal, 2(3), 42-54. https://doi.org/10.33697/ajur.2003.020

Nazaretha, R., Mudzaqi, M. A., Ghani, N. A. Al, \& Hutajulu, M. (2019). Kelas VIII pada Materi Sistem Persamaan Linear Dua. Journal On Education, 01(03), 438-445.

NCTM. (2000). Principles and Standards for School Mathematics. The National Council of Teachers of Mathematics, Inc. 
Nurainah, Maryanasari, R., \& Nurfauziah, P. (2018). Analisis Kesulitan Kemampuan Koneksi Matematis Siwa SMP Kelas VIII pada Materi Bangun Datar. Jurnal Pembelajaran Matematika Inovatif, 1(1), 37 43. https://doi.org/10.22460/jpmi.v1i3.219-228

Nursaniah, L., Nurhaqiqi, \& Yuspriyati, D. N. (2018). Analisis Kemampuan Koneksi Matematik Siswa Smp Pada Materi Bangun Ruang Sisi Datar. Jurnal Pembelajaran Matematika Inovatif, 1(5), 857-862.

Rawa, N. R., Sutawidjaja, A., \& Sudirman. (2016). Kemampuan Koneksi Matematis Siswa Kelas X pada Materi Perbandingan Trigonometri. Prosiding Seminar Nasional Pendidikan Matematika Universitas Negeri Malang, 911-923.

Siagian, M. D. (2016). Kemampuan Koneksi Matematik Dalam Pembelajaran Matematika. MES (Journal of Mathematics Education and Science), 2(1), 58-67.

Siregar, N. D., \& Surya, E. (2017). Analysis of Students' Junior High School Mathematical Connection Ability. International Journal of Sciences: Basic and Applied Research (IJSBAR), 33(2), 309-320.

Sudihartinih, E. (2018). Analisis Kesalahan Siswa dalam Konsep Titik dan Garis pada Bidang. Erudio (Journal of Educational Innovation), 5(1), 12-18. https://doi.org/10.18551/erudio.5-1.2

Sudirman. (2017). Analisis Kemampuan Koneksi Matematis Siswa SMP Pesisir Ditinjau dari Perbedaan Gender. Prosiding Seminar Nasional Riset Kuantitatif Terapan 2017, 131-139.

Sugiman. (2008). Koneksi Matematik dalam Pembelajaran Matematika di Sekolah Menengah Pertama. Pythagoras, 4(1), 56-67.

Wahyuningrum, A. S., Suryadi, D., \& Turmudi, T. (2019). Learning Obstacles among Indonesian Eighth Graders on Ratio and Proportion. Journal of Physics: Conference Series, 1320(1), 1-8. https://doi.org/10.1088/1742-6596/1320/1/012046

Wardina, A. S., \& Sudihartinih, E. (2019). Description of Student'S Junior High School Mathematical Connection Ability on the Linear Function Topic. Journal of Mathematics Science and Education, 2(1), 24-35. https://doi.org/10.31540/jmse.v2i1.813

Warih, P. D., Parta, I. N., \& Rahardjo, S. (2016). Analisis Kemampuan Koneksi Matematis Siswa Kelas VIII pada Materi Teorema Pythagoras. Prosiding Konferensi Nasional Penelitian Matematika Dan Pembelajarannya [KNIP I], Knpmp I, 377-384.

Zuyyina, H., Wijaya, T. T., Senjawati, E., P, H. M., \& Senjawati, E. (2018). Kemampuan Koneksi Matematis Siswa SMP pada Materi Lingkaran. Jurnal LP3M-Universitas Sarjanawiyata Tamansiswa Yogyakarta, 4(2), 79-90. 